\title{
Sciendo
}

\section{Dysfunctionality from the Sovereignty Conflict in the ATAD GAAR}

\author{
Kaido Künnapas \\ TalTech Law School, \\ Tallinn University of Technology \\ Ehitajate tee 5, \\ Tallinn 19086, Estonia \\ Email: kaido.kunnapas@taltech.ee
}

\begin{abstract}
Deriving from the internal structure of Article 6 of the EU Anti-Tax Avoidance Directive, the abuse of tax law is overcome in two stages-elimination and requalification. While the elimination stage (addressing how not to tax) is harmonized by the EU for the purpose of fighting against aggressive tax planning, the requalification stage (addressing how to tax then) remains under the sovereignty of Member States. Applying such a two-level mechanism becomes problematic if there is a mismatch between these two stages so that the harmonized GAAR requires elimination of an arrangement, but the domestic law does not provide an alternative basis for taxation of it. This raises a question of whether Article 6 of the ATAD requires the Member States to impose new taxable objects regardless of the literal interpretation of Article 6(3) which recognizes the full sovereignty of Member States to decide what to tax. By applying interpretation methods used by the CJEU in its case-law-i.e., literal, contextual, teleological and comparative-the author argues that the answer to this question is "no". This is supported by all the interpretations under the above method, while the dysfunctionality of these two stages could be overcome by treating the economic reality test as an objective test regardless of the notion of "commercial reasons" used in Article $6(2)$.
\end{abstract}

Keywords: artificial arrangements, ATAD, capitalization scheme, Estonia, general anti-abuse rule, income, interpretation methods, subsidiarity, tax sovereignty 


\section{Introduction}

Article 6 of the EU Anti-Tax Avoidance Directive (ATAD) introduces the general anti-abuse rule (GAAR) for tax matters. Being lifted from the antiabuse doctrines found in primary EU law and anti-abuse provisions found in secondary EU law (de Wilde, 2018, ch. 14.1.), it provides a minimum level of protection for national corporate tax systems against tax avoidance practices across the European Union (EU) (ATAD, Recital 11 and Art. 3). More specifically, it requires to set aside, for tax purposes, "non-genuine arrangements which have been put into place for the main purpose or one of the main purpose of obtaining a tax advantage that defeats the object or purpose of the applicable tax law". Notably, in recent case-law, the Court of Justice of the European Union (CJEU) has started to use similar wording for the anti-abuse doctrine (Joined Cases of $N$ Luxembourg 1 and Others $v$. Skatteministeriet [2019]).

(i) Deriving from the internal structure and literal interpretation of Article 6, the abuse of tax law is overcome in two stages-elimination and requalification:

(ii) The abusive arrangement is eliminated if the subjective and objective conditions of anti-abuse test in the ATAD have been met. The elimination stage is harmonized ${ }^{1}$ within the EU, categorizing certain transactions to be non-existing in terms of taxation.

The abusive arrangement is requalified for tax purposes, i.e., it is taxed according to the domestic law. Supported by the literal interpretation of Article 6(3) of the ATAD, the requalification mechanism is not harmonized, which means that the Member States have full sovereignty to decide whether and how to tax abusive arrangement. Neither the ATAD nor EU law in general dictate to the Member States what should be the taxable objects.

Applying such two-level mechanism becomes problematic if there is a mismatch between these two stages so that the harmonized GAAR requires elimination of the arrangement, but the domestic law does not provide an alternative basis for taxation of it. Such mismatches exist because the elimination stage is harmonized and is not relying fully on domestic tax law, but the requalification stage has been left for the Member States to furnish. One may face such a situation when, for example, the ATAD requires

$1 \quad$ As the ATAD provides a minimum level of protection under its Article 3, Member States can design anti-abuse rules which enable them to requalify a wider spectrum of arrangements. 
elimination of an arrangement due to a lack of commercial reasons (reasons being subjective elements by their nature) present in the economic reality, but the domestic law enables taxing the questionable arrangement based on the objective content (economic reality) which corresponds to one of the eliminated arrangements. ${ }^{2}$ There would be no such issue if the elimination stage relied fully on domestic law. This, however, may not be the case as the core idea of harmonization is to create new domestic standards to prevent abuse. Some have even seen the ATAD as "a first step towards a more general harmonization of tax bases" (Gutmann, 2017, p. 57).

In the context of the comparative method used in this article, the author demonstrates such a mismatch through a case study of a two-step company capitalization method used in Estonia (Scheme) ${ }^{3}$. Such Scheme got the attention of the Estonian legislature upon transposing the ATAD into the Estonian Income Tax Act (ITA). The initial version of the explanatory memorandum to ITA bill argued that such Scheme should be set aside from taxation under the new GAAR. ${ }^{4}$ Acknowledging the need to eliminate such an arrangement from taxation and facing the fact that the transaction would be otherwise completely exempt from tax, a new taxable object of 'income not received' was introduced by the legislature in the draft ITA law no. $705 \mathrm{SE}$ as it was seen as inevitable for implementing the ATAD as per explanatory memorandum. This new tax base would have enabled attribution of the company's income to the contributor and taxed as the contributor's income not subject to deferral. Such an approach, however, would not have been in line with the principle of separation of assets of the company and its shareholders, and it would have deviated significantly from the economic reality. The legislature abandoned this approach just before the last step of the legislative process in order to prevent delay of the implementation of the ATAD.

2 Under Estonian law, the legal facts relevant in taxation must be identified through the economic content of the arrangement (in Kõrgesaar v. Tax Board [2001]).

3 First, the company is capitalized by a natural person (shareholder) who makes a non-monetary contribution to the equity of the company. This is followed by a sale of such asset by the company, receiving capital gains from such a sale. While companies enjoy general deferral of the corporate income tax until the profits are distributed, the natural person shareholder would not have been eligible for such deferral. This can be seen as a tax advantage for the natural person shareholder, if to attribute the company's income to natural person shareholder.

4 Indeed, assets are often "sold through" the company with one of the purposes to postpone the tax liability of the contributor by using the deferral of corporate income tax applicable to corporate taxpayers. Also, the commercial reasons for using such a Scheme may deviate from the commercial reality, which can be illustrated by making an investment into a company which may not have a clear business need for such equity investment at the time of capitalization. 
The contradiction addressed above and the example of the Scheme leads to the question of whether the elimination rule in the ATAD GAAR is indeed a pure elimination rule or whether it interferes with the sovereignty of Member States to define on taxable objects. The research question of this article is: Does Article 6 of the ATAD require Member States to impose new taxable objects regardless of the literal interpretation of Article 6(3) which recognizes the full sovereignty of the Member States to decide what to tax? As the tax advantage test requires comparable transactions, it also addresses which transactions one should compare when identifying the tax advantage and how the gamechanging subjective element in the ATAD's elimination test affects it.

As the literal interpretation of Article 6 of the ATAD led to the research question, the author applies other interpretation methods used by the CJEU in its case-law-i.e., contextual, teleological and comparative-to answer the question (Lenaerts \& Gutierrez-Fons, 2013). Contextual and teleological interpretation methods are often interlinked, therefore the author first analyses the function of the ATAD in the context of primary law, after which the focus is turned to identifying the intent of the legislature. As for the comparative method, the author compares Estonia's long-standing anti-avoidance approach to the Scheme to highlight the issue and propose solutions. Although the Scheme is often approached as a personal income taxation issue (the scenario taxpayers usually try to avoid), it also involves corporate income tax element (the scenario the taxpayers usually aim). As the Scheme is also about determining the corporate tax liability (or lack of such liability to be exact), the genuineness of the Scheme can be analysed under ATAD GAAR.

\section{Contextual approach to the limits of tax sovereignty under the ATAD}

\subsection{Articles 113 and 115 of the TFEU}

According to Lenaerts and Gutierres-Fonz,

[i]nternally, contextual interpretation focuses on the purely normative context in which the EU law provision in question is placed. Just as the different parts of an engine must work together to keep it running, the ECJ looks at the functional relationship between the EU law provision in question and the normative system to which it belongs. (Lenaerts \& Gutierrez-Fons, 2013, p. 13) 
Furthermore, "[i]t follows that, where an EU law provision may be subject to several interpretations, the ECJ must give priority to that which guarantees compliance with primary EU law and ensures its effectiveness" (Lenaerts \& Gutierrez-Fons, 2013, p. 16). One can see it as a systematic interpretation, seeking support from the higher-level norms.

In this research, internal contextual interpretation is about fitting the requalification stage and the national tax sovereignty into the context of the primary EU law, which provides a framework for the ATAD GAAR. To start with, it is necessary to identify alternative interpretations which Article 6 may provide. There are two alternative ways that Article 6(3) could be interpreted in conjunction with Sections (1) and (2) of the same article. The first possible interpretation is that the full sovereignty to decide what to tax is recognized. The alternative interpretation is that the sovereignty to decide tax bases is limited as there may be a need to introduce new tax bases for arrangements which are set aside based on the elimination test.

The ATAD is established under Article 115 of the Treaty of Functioning of the European Union (TFEU). It provides a general basis for adopting EU legislation for the purpose of ensuring the proper functioning of the internal market (Consolidated version of the TFEU, Art. 115). One threat hindering the proper functioning of the EU's internal market that has prompted the Commission to introduce an anti-avoidance package is aggressive tax planning (ATAD, Recital 3). As per the proposal for a Council Directive laying down rules against tax avoidance practices that directly affect the functioning of the internal market, the aggressive tax planning schemes the ATAD targets involve acting against the actual purpose of the law. It follows that ATAD harmonizes the anti-abuse tools, which are to ensure that the domestic tax laws are applied according to their purpose and the legislature's intent.

The political objective of this measure is to close any gap with respect to existing targeted or national anti-abuse rules in the area of corporate taxation (Rigaut, 2016, ch. 3.4.). Article 115 of the TFEU does not provide a basis for introducing new tax bases for corporate income tax or other types of direct taxes. Direct taxation falls outside of the competence of the EU as per Article 113 of the TFEU, being therefore an integral part of the sovereignty of Member States.

Indeed, the EU has been reluctant to harmonize direct tax legislation, as this is a very sensitive topic for the Member States from the political perspective 
(Maisuradze, 2017, p. 4). The current secondary law in direct taxation adopted by reference to Article 115 of the TFEU or Article 94 of the Treaty establishing the European Community (TEU) is intended to limit the tax base if double taxation may prevent exercising fundamental freedoms and therefore undermine the common market principle. According to Rigaud,

[t]he PSD and IRD, in particular, are legal tools primarily looking at removing withholding taxes within the European Union in order to avoid double taxation and facilitate single market integration; they are less equipped for dealing with double non-taxation issues, and even less so for dealing with BEPS issues in relation to third countries. (Rigaut, 2016, ch. 4)

Such secondary law, however, does not introduce any new taxable objects. Although it is argued that ATAD opens new horizons for the harmonization of direct taxation (Rigaut, 2016, ch. 1; Maisuradze, 2017, p. 5), it should not be seen as harmonizing the tax base and requiring the introduction of new taxable objects.

The above is supported by the Recital 1 of the ATAD, which state that the purpose of introducing a harmonized anti-abuse rule is to "allow the governments to effectively exercise their tax sovereignty". An integral part of Member States' tax sovereignty is to decide what to tax and what not to tax. Highlighting the sovereignty of Member States corroborates the approach that the ATAD is not intended to go against Article 113 of the TFEU, which does not call for harmonization of the direct tax base. Also, the high level of the sovereignty of Member States in transposing the directive into domestic laws was emphasized in the Commission's proposal for the ATAD as follows: "The text thus lays down principle-based rules and leaves the details of their implementation to Member States, on the understanding that they are better placed to shape the precise elements of the rules in a way that best fits their corporate tax systems." (Commission Proposal COM(2016) 26 final)

\subsection{Subsidiarity and the sovereignty}

In the context of this analysis, it is worth noting that introducing the elimination rule itself has been quite a stretch in terms of the subsidiarity principle.

The principle of subsidiarity draws a line between the legislative powers of the EU and the Member States. This principle derives from Article 5(3) of 
the Treaty of the European Union and Protocol No. 2 on the application of the principles of subsidiarity and proportionality. In its judgment of 4 May 2016 in case C-547/14, Philip Morris Brands SARL and Others v. Secretary of State for Health [2016], the Court of Justice of the European Union stated that it limits the powers of the EU to act in areas which do not fall within its exclusive competence, if and insofar as the objectives of the proposed action cannot be sufficiently achieved by the Member States and can, therefore, by reason of the scale or effects of the proposed action, be better achieved at the EU level.

The ATAD has faced objections since its birth. The Swedish and Maltese parliaments presented their objections to the ATAD based on the infringement of the principle of subsidiarity (Cedelle, 2016, p. 492). The Swedish parliament highlighted the importance of taxation sovereignty for the Member States in the case of direct taxation since it belongs to the national competence of each Member State. Furthermore, regarding the proposal for a Council Directive laying down rules against tax avoidance practices that directly affect the functioning of the internal market, "[t]he Riksdag notes that the proposal was produced in a very short period of time, and that it is very extensive and is burdened with a distinct lack of clarity" (Statement by the Committee on Taxation 2015/16:SkU28). The Maltese House of Representatives was even more critical and highlighted the infringement of the principle of subsidiarity both from a procedural and a material point of view (Maisuradze, 2017, p. 32). There is, however, no subsidiarity analysis made specifically on Article 6(3) of the ATAD.

The author does not intend to carry out a full analysis on the compliance of the ATAD to the principle of subsidiarity as there have been academic discussions on that topic already (Maisuradze, 2017, p. 24; Lazarov \& Govind, 2019, pp. 852-868). However, acknowledging that the elimination rule in the ATAD GAAR lies rather in the periphery of the competence of the EU, especially in situations when applied to domestic arrangements, the subsidiarity problems with the elimination rule support a rather broad and not restrictive interpretation of the wording of Article 6(3) and domestic sovereignty in "what to tax".

Summarizing the above, the author finds that the internal contextual interpretation of Article 6(3) of the ATAD, in conjunction with Articles 113 and 115 of the TFEU, supports the literal approach that it does not require the Member States to introduce new taxable objects if the arrangement should be set aside as abusive under the elimination rule. Taking the 
opposite position would be highly questionable also in the context of the principle of subsidiarity which supports a rather broad interpretation of Article 6(3) and the notion of tax sovereignty in it.

\section{Teleological approach to the limits of the ATAD}

\subsection{Intent of the legislature in travaux préparatoires}

Schønberg and Frick (2003, p. 149) have noted that ECJ is paying more attention to travaux préparatoires when interpreting secondary EU legislation. According to Lenaerts and Gutierres-Fonz, "[w]hilst travaux préparatoires play a limited role when compared with other methods of interpretation, their role is far from being marginal. On the contrary, it seems that they may well become increasingly important in the years to come." (Lenaerts \& Gutierres-Fonz, 2013, p. 22). The preparatory legislative materials can shed light on the intent of the legislature and provide guidance on how to understand the interaction between the elimination and requalification rule.

Among others, travaux préparatoires include the Commission's legislative proposals. The issue of interaction between the sovereignty to tax and the elimination rule was not addressed in the Commission's proposal for the directive. Instead, the EU Commission only held in the proposal for a Council Directive laying down rules against tax avoidance practices that directly affect the functioning of the internal market that "[i]n compliance with the acquis, the proposed GAAR is designed to reflect the artificiality tests of the CJEU where this is applied within the Union", followed by "[i]t would allow authorities the power to deny taxpayers the benefit of abusive tax arrangements" (Commission Proposal COM(2016) 26 final). It seems to merely highlight the function of GAAR as being a supplementary tool for the national tax authorities to fight artificial arrangements.

When comparing the initial and final versions of the ATAD, it is interesting to observe that the latter one is less invasive in terms of the requalification stage. Namely, the initial version of the directive required the Member States to tax the eliminated transactions based on their economic substance in accordance with national law (Rigaut, 2016, p. 502). The reference to the economic substance was removed from the wording due to it being an unknown concept in some domestic laws of Member States. The final wording of the ATAD refers only to taxation under "national law and allows 
for complete flexibility as part of the national transposition process". This amendment made during the legislative process supports the interpretation that the ATAD is not intended to prescribe the taxable objects to the Member States, but rather it is intended only to harmonize the elimination of certain transactions. Such an approach is in line with the EU's view on the sovereignty of Member States in direct tax matters. Direct tax matters have mostly been left to the Member States to regulate, whereas the CJEU has been the driving force for the harmonization (Lehis, 2012, p. 245).

In conclusion, the author finds that the legislature's intent as seen in the Commission's proposal for the directive confirms that Article 6(3) of the ATAD should be interpreted literally, leaving the Member States full sovereignty in deciding the object and purpose of their tax laws. It does not require the Member States to change the concept of income or introduce new taxable objects to enable elimination of arrangements for which there are no alternative taxable bases.

\subsection{Conflict of objective and subjective taxation in the effet utile test}

\subsubsection{Source of potential dysfunctionality in GAAR}

Assuming the common sense of a legislature, the effet utile interpretation method lets us assume that no provision in the law is redundant (Lenaerts \& Gutierres-Fonz, 2013, p. 14). Every provision of a law should be interpreted in such a way that it retains its effectiveness and function, preferably to the full extent. While the elimination and requalification rules in the ATAD GAAR function well when applied in isolation, application in conjunction with each other may limit the functionality of either the elimination or the requalification rule as follows:

A. If the elimination rule is applied in full, the arrangement is set aside for subjective reasons, and there is no alternative basis for taxing the eliminated arrangement, the tax sovereignty in Article 6(3) is limited. It may require introducing new tax bases as the final outcome of elimination cannot be non-taxation of an abusive arrangement.

B. Alternatively, if the sovereignty to decide tax bases is recognized in full, the elimination of certain arrangements (e.g., because the commercial reasons asserted by the taxpayer are not reflected in economic reality) may not have the intended effect as the requalification under the domestic tax law would lead to the same outcome (e.g., the actual 
economic content of the arrangement remains the same regardless of the commercial reasons for it).

This leads to the question of whether a Member State should acknowledge the supremacy of the elimination rule and introduce a new tax base for an eliminated arrangement, provided the only possible tax base was eliminated, or, alternatively, acknowledge the supremacy of the existing domestic tax law and not eliminate the arrangement under the GAAR when facing that situation. In both cases, either the elimination rule or the requalification rule becomes partly dysfunctional and limited in its scope.

\subsubsection{Overcoming the dysfunctionality}

The main objective of introducing the GAAR is to establish an EU-wide minimum standard for arrangements which should be considered abusive and which should be non-existing from the tax perspective. Therefore, the GAAR should first and foremost be functional with respect to the elimination of abusive arrangements as this is the core function of Article 6 of the ATAD. Although an important part of the GAAR, recognizing the tax sovereignty is not the main function of the GAAR.

To sustain the functionality of the requalification stage in Article 6(3), it is first necessary to analyse whether it is possible to interpret the elimination rule so that the sovereignty to decide the tax base is recognized within the elimination rule. Such an approach would enable both the elimination rule and requalification rule to function to the full extent and would follow the principle of effet utile the most. If no such interpretation is possible, only then should one consider interpretations of Article 6, which would limit either the functionality of the elimination rule or the requalification rule (preferred).

The elimination rule in GAAR consists of two tests-a tax advantage test ${ }^{5}$ and an economic reality test ${ }^{6}$. As per the tax advantage test, the domestic tax law is attracted to this stage through the notion of the object or purpose of the applicable tax law. However, as the subjective criteria of "the main purpose or one of the main purposes" is an independent definition in the

5 Described as "having been put into place for the main purpose or one of the main purposes of obtaining a tax advantage that defeats the object or purpose of the applicable tax law" in the ATAD, Art. 6(1).

6 Described as "are not genuine having regard to all relevant facts and circumstances" in the ATAD, Art. 6(1) and "[a]n arrangement or a series thereof shall be regarded as non-genuine to the extent that they are not put into place for valid commercial reasons which reflect economic reality" in the ATAD, Art. 6(2). 
directive, it is not possible to reduce the tax advantage test to domestic concepts only.

Dysfunctionality with respect to the economic reality test might be overcome if it could be treated as an objective test. ${ }^{7}$ So the question to be answered is whether the economic reality test is an objective or subjective test from the perspective of the taxpayer's intentions.

\subsubsection{From 'justifications' to 'considerations': a play between taxation in reality and intentions}

The ATAD GAAR is sourced from the anti-abuse doctrine developed by the CJEU (de Wilde, 2018, ch. 14.1.). The pre-ATAD anti-abuse doctrine developed by the CJEU was objective. There was no tax abuse when the economic substance corresponded to the legal form in which the taxpayer has wrapped the transaction (de Wilde, 2018, ch. 14.1.). The driving motives of the taxpayer, however, are irrelevant for determining abuse, provided the legal form of the arrangements under question corresponded to the economic content (de Wilde, 2018, ch. 14.1.). In Cadbury Schweppes [2006], the court stated "[n]ational measure restricting freedom of establishment may be justified where it specifically relates to wholly artificial arrangements aimed at circumventing the application of the legislation of the Member State concerned" (Cadbury Schweppes [2006], p. 51). In his opinion, the Advocate General Mr. Leger used a more detailed three-level objective test, assessing (i) whether the subsidiary was genuinely established, (ii) whether it provided services of a genuine nature, and (iii) whether it created any value for the parent company (Leger, 2006, paras. 111-114). The objective nature of the economic reality test was ascertained by the CJEU in the recent case of $N$ Luxembourg 1 and Others $v$. Skatteministeriet [2019], in which the court noted that it

is clear from the Court's case-law, proof of an abusive practice requires, first, a combination of objective circumstances in which, despite formal observance of the conditions laid down by the EU rules, the purpose of those rules has not been achieved and, second, a subjective element consisting in the intention to obtain an advantage (Joined Cases of $N$ Luxembourg 1 and Others v. Skatteministeriet [2019], pp. 124-125)

As the initial idea of harmonization is to provide minimum standards and some Member States may not meet such standards, it is evident that the conflict between domestic tax law and independent concept of GAAR may remain. However, the author assumes that the objective facts are generally accepted as the basis for taxation instead of intentions and motives of the taxpayer. 
The court used the notion of "purely formal or artificial transactions devoid of any economic and commercial justification" in $N$ Luxembourg 1 and Others v. Skatteministeriet [2019], relying on the concept of justification. However, by doing so, the court made a reference to the Newey case from 2013 in which the objective notion of "wholly artificial arrangements which do not reflect economic reality" was used (Newey [2013], paras. 47-49). Furthermore, the criteria which were taken into account in the economic reality test in the case of $N$ Luxembourg 1 and Others v. Skatteministeriet [2019], paras. 130131 were of the objective nature.

The author finds the approach adopted by the CJEU supports the idea of objective taxation. It means that taxable events should be defined based on factual events taking place and not based on the motives of the taxpayer. This approach is supported by the principle of equal treatment of taxpayers, which is based on one of the four fundamental principles in tax law-equity (de Wilde, 2018, ch. 14.1.). Equal treatment can be divided into horizontal and vertical equity. According to Pistone,

Horizontal equity may be defined as a variant of the principle of individual equity that holds that similarly situated taxpayers should receive similar tax treatment, e.g. taxpayers who earn the same amount of income or capital should be taxed in the same way. [...] A variant of the principle of individual equity, which holds that differently situated taxpayers should be treated differently. (Pistone, 2019, ch. 2.1.2.)

It relies on objective categories as opposed to subjective categories when it comes to determining taxable events.

The ATAD GAAR introduced a new concept of the economic test, drafted as "not put into place for valid commercial reasons which reflect economic reality". As one can observe, the notion of justification was replaced by reasons. It follows from the literal interpretation of Article 6(2) of the ATAD that the wholly artificial arrangement as an objective category used by the CJEU has been replaced by non-genuine arrangement as an objectivesubjective mixed category, relying on the reasons why the taxpayer chose the form for the arrangement. According to de Wilde (2018, para. 14.2.2.4.), the reasons should be understood as considerations.

When following the literal interpretation, it may become problematic for the Member States which follow the approach of objective taxation to find a legal basis to tax the transaction eliminated under the ATAD GAAR. First, to avoid overall non-taxation of the arrangement under question, it may require 
allocation of income to another entity which actually has not received any income, therefore deviating from the commercial reality. Secondly, it may classify the arrangement as one which is excluded from taxation for some other reason. The literal interpretation, therefore, limits the functionality of either the elimination or the requalification test.

However, relying on the continuity of EU case-law, it should be possible to interpret the GAAR's economic reality test as an objective test. As Richard Collier argues, "[t]he ATAD GAAR is designed to be compliant with the freedoms by applying only to arrangements that are not genuine, consistent with the interpretation by the Court of Justice of the Treaty freedoms in the Cadbury Schweppes case" (Collier, 2018, p. 11). Since the CJEU has used the concept of wholly artificial arrangement as an objective category (Cadbury Schweppes plc and Cadbury Schweppes Overseas v. Commissioners of Inland Revenue [2006], para. 75), such an approach would be in line with the underlying ideology of the ATAD. Such continuity can also be inferred from the recent judgment in $N$ Luxembourg 1 and Others $v$. Skatteministeriet [2019], where the court, after spending a large part of the ruling describing the genesis of the anti-tax abuse doctrine in its case-law, summarized the anti-abuse rule in the wording used in Article 6 of the ATAD. ${ }^{8}$ The functionality of both the elimination test and requalification test can be retained if the concept of reasons used in Article 6(2) of the ATAD is treated as objective by its nature. It is eventually up to the CJEU to explain how to understand this concept and whether such an approach could be accepted.

$8 \quad$ See para. 127 of the Judgment, stating: "A group of companies may be regarded as being an artificial arrangement where it is not set up for reasons that reflect economic reality, its structure is purely one of form and its principal objective or one of its principal objectives is to obtain a tax advantage running counter to the aim or purpose of the applicable tax law." In the context of tax advantage test it is even more interesting to observe how the concept of "sole aim of obtaining tax advantage" used in Newey [2013] (referred to in para. 125) changes to the "essential aim of benefiting from an improper advantage" (used in para. 125), from which it evolves to the "principal objective or one of its principal objectives is to obtain a tax advantage". 


\section{Comparative approach to the anti-avoidance rule under Estonian law}

\subsection{The method}

According to Lenaerts and Gutierrez-Fons (2013, p. 35), "Article 19 TFEU provides the constitutional authority for the ECJ to engage in a comparative study of the laws of Member States." The ECJ must take into account the legal systems of the Member States when discovering and developing the general principles of EU law as "the comparative law methodology reinforces the legitimacy of the ECJ" (Lenaerts \& Gutierrez-Fons, 2013, p. 37). As per the methodology,

[w]ith a view to ascertaining the different interpretative options available in national legal systems, the ECJ will at first have recourse to the comparative law method in order to identify them. Next, the ECJ will choose the option which is best suited to the attainment of the objectives pursued by the EU. (Lenaerts \& Gutierrez-Fons, 2013, p. 40)

The author uses the Scheme to provide an example of how Estonian law enables to eliminate and requalify arrangements and how the dysfunctionality has been overcome in the practice of the Estonian Supreme Court. By applying the domestic GAAR, which was introduced long before ATAD came into force (the old GAAR), the author demonstrates how it resolved such conflict without any need to introduce new taxable objects. The author cannot provide a comparison based on the new domestic GAAR, which copies the wording from ATAD (the new GAAR), as there is no case-law available yet and the interpretation from the bill of law of ITA was removed during the legislative process. However, as ATAD GAAR is sourced from the prior caselaw of the CJEU and the compatibility of the old Estonian GAAR has never been challenged in that respect, the old Estonian GAAR should reflect the same type of protection, which is provided under ATAD GAAR. Following this, the author analyses how the domestic GAAR addressed the problem of lacking basis for taxation, using the example of the Scheme.

\subsection{Legal form of the Scheme}

The Scheme usually involves a natural person shareholder (shareholder) who has an asset (asset). Additionally, this natural person has a company (company) in which this natural person owns shares, and a third party (third party) eventually acquires the asset. The transactions in which the 


\section{Scheme 1. Step-by-step legal form of the Scheme}
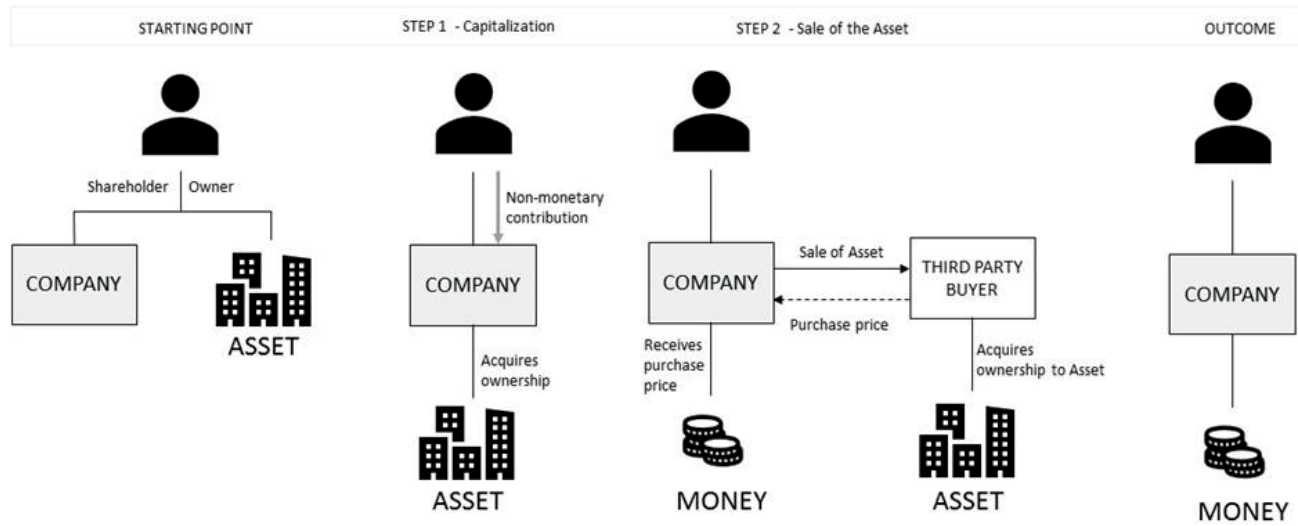

question of tax avoidance arises usually relate to new companies that have no other activities besides the acquisition of the equity contribution through a capital contribution and the sale of the asset to a third party entity paying consideration to the company. The shareholder may plan to alienate the asset in the future or already may have a plan to alienate it to the third party when making a contribution to the company's equity. The asset is usually real estate or shareholding in a company. However, under Section 142(1) of the Estonian Commercial Code (CC), it can be any transferrable asset which has identifiable value.

As the first step, the shareholder makes a capital contribution to the equity of the company by making a non-monetary payment to the equity. As a result, the ordinary monetary value of the asset is registered in the equity (whether in the share capital, share premium or some other equity instrument) as a payment made by the shareholder. The asset is in the legal and economic ownership of the company, which means that the company has the freedom to decide how it uses the asset. If the company is not able to fulfil its obligations towards third parties, the asset can be alienated by the bankruptcy administrator and the sale proceeds can be used to perform the company's monetary obligations towards third parties. The author determines from these facts that the asset is in the economic ownership of the company.

As a second step, the company can sell the asset to a third party for a certain price. When the company receives the payment from a third party, it obviously receives business income. The purchase price received stays in the economic ownership of the company, which means that the company can 
reinvest it (for example, buying some equipment necessary for its business activities) or retain it by keeping it in its bank account. It is also evident that the shareholder of the company has the ultimate right to dictate how the company will use this asset in its business activities or whether it will be distributed as a profit.

\subsection{Taxation of the Scheme based on its legal form}

Making a non-monetary equity contribution to a company does not create a tax liability for the shareholder (ITA, Section 15(4(10)). The Estonian ITA states that making or having a non-monetary equity contribution to the company is to be treated as income; however, it is excluded from taxation. The reasoning behind such an approach chosen by the legislature is not presented in the law. The ITA stipulates neither the principles of taxation nor the definition of income (Lind, 2003, p. 338).

It is evident that the shareholder receives income if it receives shares in the company in consideration for a non-monetary equity payment made by some other shareholder. On the contrary, the author finds that a natural person shareholder transferring an asset to a company in his or her sole ownership shareholding should not be treated as income received by such natural person shareholder. Income should increase the balance of assets the person has-this is one characteristic of the concept of income (Lind, 2003, p. 341). In case of switching the ownership of the asset with the ownership of the shares of the company which acquires this asset, the balance of the value of assets of the shareholder remains the same. Therefore, the author finds that the concept of income used in Section 15(4(10)) of the ITA is in line with the theoretical concept of income on which the Estonian ITA is based.

As for the second part of the arrangement, business income (including capital gains) received by an Estonian corporate entity is not subject to corporate income tax upon receipt. Estonia applies corporate income tax on a deferred basis. This means that the corporate income tax falls due only upon making profit distributions or transactions having the equivalent effect to profit distributions (such as making gifts, covering non-business expenses, or granting fringe benefits to employees). The Estonian corporate income tax system is designed to encourage enhanced reinvesting the profits earned by deferring the corporate income tax liability until the profit is distributed (Lehis, 2012, p. 290). This is to be taken into account when assessing whether granting such tax benefit, if any, in the form of tax deferral is in 
line with the purpose of Estonian corporate income tax system. ${ }^{9}$ It follows that the sales proceeds received from the sale of assets to third-party buyers enjoy exemption from corporate income tax until it is distributed as profit or equivalent payments/transactions are made to the shareholder.

\subsection{Taxation of the Scheme based on its economic content}

\subsubsection{The domestic anti-avoidance rule}

As the new ATAD-based GAAR is effective as of the beginning of the year 2019 , there is no court practice on that regulation yet. However, the Estonian Supreme Court has analysed the taxation of the Scheme in the context of the general domestic anti-avoidance regulation which was applicable to income tax matters before implementing the income tax-specific ATAD regulation, i.e., at the time when the anti-avoidance rule designed by the CJEU was applied as a general principle of EU law.

Section 84 of the Estonian Taxation Act (TA) states that if it is evident from the content of a transaction or act that the transaction or act is performed for the purposes of tax evasion, conditions that correspond to the actual economic content of the transaction or act apply upon taxation.

It follows that the Estonian anti-avoidance regulation, which was also effective before implementing the ATAD, already addressed the subjective element, requiring that it should be taken into account upon application of the domestic GAAR. However, the difference lies in the importance of the intent to obtain a tax benefit by using the arrangement. While the ATAD states that an arrangement with the main purpose or one of the main purposes of obtaining a tax advantage has to be set aside when being nongenuine, Estonian regulation just states that the transaction should be set aside when done for the purpose of tax avoidance, following the taxation based on economic substance. In its wording, Section 84 of the TA seems to be even broader compared to ATAD when it comes to criteria used to set the transaction aside.

The second important difference between the ATAD-based GAAR and domestic GAAR in Section 84 of the TA is that the latter addresses the second step of the reassessment procedure-the requalification stage, i.e.,

$9 \quad$ Further on the tax advantage see the Communication from the Commission C(2012) 8806 final, p. 4.4.: "In determining whether an arrangement or series of arrangements has led to a tax benefit, national authorities are invited to compare the amount of tax due by a taxpayer, having regard to those arrangement(s), with the amount that the same taxpayer would owe under the same circumstances in the absence of the arrangement(s)". 
how the transaction which has been set aside should actually be taxed. It states that the transaction should be taxed according to the economic content. The economic content must be identified according to the factual outcomes of the transaction, which include the transfer of money or assets. It follows that the economic content is determined based on the objective criteria as being an objective category.

\subsubsection{The Supreme Court practice}

In one of the landmark cases from the year 2012, Maret Lilleorg v. MTA [2012], the Estonian Supreme Court elaborated on a set of transactions under which the natural person alienated shares in a company through another company in her ownership. The facts of the case were similar to the facts of the Scheme described above, and, in addition, the assets were sold to the company at a price below the market rate (Maret Lilleorg v. MTA [2012], p. 4). It is notable that the company did not have economic substance at the moment of this transaction other than keeping the shares and selling them shortly after the acquisition. This indicates that the purpose of implementing such a transaction setup was to avoid capital gains tax as a natural person at the time of making the transaction, and instead to benefit from the deferred corporate income tax system under which the company operated.

In the second landmark case, Marge Sirge v. MTA [2011], the facts of the case were similar to what is described above, however, with the exception that the asset was transferred to the equity of the company by making a non-monetary contribution to the equity.

In both cases, the tax authorities argued that the purpose of organizing the set of transactions in such a way was to receive a tax advantage by postponing the natural person's tax liability. In the context of tax advantage, the taxpayer's and tax authority's view is presented in Scheme 2 below.

In both court cases, the main question analysed by the Supreme Court was whether capitalizing the company and selling the asset used for capitalization right after entails a tax advantage for the natural person shareholder. The Supreme Court applied the anti-abuse rule in Section 84 of the TA in both cases, but, differently from the tax authority's approach, found that such Scheme does not lead to requalification of transactions and taxation of the company's capital gains as a natural person's income.

The core of the court's argument was that the placement of money in a business can not provide a tax benefit, provided the natural person shareholder is not 
able to use the company's money for its own benefit without paying any taxes. While the Supreme Court was hesitant when analysing the economic content of the sale of shares transaction at a purchase price significantly below the market price, the court found that capitalizing the company via a transfer of shares transaction corresponds to the economic content of the capitalization method which is regulated in Section 142 of the Commercial Code (p. 16). However, it was emphasized by the Court that it is important to find out whether the natural person shareholder has used the company's receivables from the sale for his or her personal purposes without paying any taxes on that (p. 18). In these cases, there was no evidence of such a fact. It follows that there was no tax advantage entailed in the Scheme.

Scheme 2. Comparable transactions in tax advantage test in the cases of Maret Lilleorg v. MTA [2012] and Marge Sirge v. MTA [2011]

\begin{tabular}{|l|l|l|}
\hline Content & $\begin{array}{l}\text { Comparable no. 1 } \\
\text { (taxpayer's view) }\end{array}$ & $\begin{array}{l}\text { Comparable no. 2 } \\
\text { (tax authority's view) }\end{array}$ \\
\hline Tax object & $\begin{array}{l}\text { Campanatization of a } \\
\text { the sale of the asset } \\
\text { used for capitalization. }\end{array}$ & $\begin{array}{l}\text { The sale of the asset } \\
\text { to the third-party } \\
\text { buyer directly by the } \\
\text { shareholder, leaving the } \\
\text { company's involvement } \\
\text { artificial. }\end{array}$ \\
\hline Tax & $\begin{array}{l}\text { Profit distribution } \\
\text { (including fringe } \\
\text { benefits) subject to tax } \\
\text { upon distribution. }\end{array}$ & $\begin{array}{l}\text { Capital gains for the } \\
\text { natural person subject to } \\
\text { tax upon receiving. }\end{array}$ \\
\hline $\begin{array}{l}\text { The natural person did } \\
\text { not pay tax, while the } \\
\text { company pays 20\% } \\
\text { (from the gross amount) } \\
\text { corporate income tax } \\
\text { only upon distribution of } \\
\text { profits or 20\% corporate } \\
\text { income tax plus 33\% } \\
\text { social tax upon making } \\
\text { fringe benefits to its } \\
\text { management board } \\
\text { member (which the } \\
\text { shareholder usually is). }\end{array}$ & $\begin{array}{l}\text { The natural person should } \\
\text { have paid personal income } \\
\text { tax at the rate of 20\% } \\
\text { from the sale proceeds }\end{array}$ \\
without any deferral. \\
\hline
\end{tabular}




\subsubsection{Acknowledgment of the principle of taxation of realized income and separation of assets}

The Supreme Court did not explain the principles of tax law behind such conclusions. However, the court presented many arguments which in the author's opinion led to a conclusion that the court acknowledged the application of the principles of the separation of assets of a company and a shareholder and the principle of taxation of realized income.

First, the Supreme Court has indicated that the taxation of a company's income becomes possible when the company distributes the purchase price to the shareholder as a (hidden) profit distribution or by giving benefits (e.g., the shareholder uses the company's apartment as a personal home without paying a rent for it). The court emphasized that "[t]he natural person avoids taxes in case this person receives an income from its economic sense and avoids tax liabilities by distorting the economic content of the transaction" (Maret Lilleorg v. MTA [2012], p. 19). It is interesting to observe that such acknowledgements were made in the context following the court's discussion on the importance of a subjective element in case of requalifying the transactions. The court stated that "[a]pplication of Section 84 is justified also if the transactions and arrangements have other goals besides having the tax advantage, from which one can be starting a business, but it is proven to be insignificant in the context of having a tax advantage" (Maret Lilleorg v. MTA [2012], p. 20). It means that although the court acknowledged the existence of a subjective element in the anti-avoidance regulation and even referred to the distinction between a significant and an insignificant effect (as does the ATAD), it did not change its approach to identifying the tax advantage and relating it to the fact of the natural person shareholder receiving income.

Secondly, the Supreme Court has stated in several court cases that the assets cannot have different owners in different procedures (decisions in cases OÜ AH Seenior v. Tax Board [2012], para. 23 and Kallas v. Estonia [2017], para. 31). The author finds that this derives from the core idea of the independent legal status of the corporate entity that the assets, risks, rights and liabilities of the shareholder and the company are separated (Saare, 2015 , p. 89). In case the transfer of the sales proceeds from the ownership of the company to the ownership of the natural person (e.g., as a fringe benefit) occurs, such transfer or asset is subject to taxation under normal deferred corporate income tax or fringe benefit tax regime according to the instructions of the Supreme Court. This also supports the author's conclusion on the existence of different ownership spheres also for tax purposes. 
The tax exemption of such non-realized income is supported by one of the fundamental principles of taxation of natural person's income, which is the principle of taxation of realized income (Lehis, 2012, p. 180; Lind, 2003, p. 342). The income is realized when the person receiving income has the actual ability to use the income for his or her own interests (Lehis, 2012, p. 180). Potential income is not realized income, and income emerges when a person receives money or consumable assets (Lind, 2003, p. 342). This is a reflection of the principle of ability to pay, which is one of the core principles of taxation.

A principle of tax economics, based on the theory that taxes should be equitable, that a taxpayer's burden should reflect his economic capacity to bear that burden relative to other taxpayers. Income is traditionally considered to be the best measure of a person's ability to pay. (Pistone, 2019, ch. 2.1.2.1.)

According to Frederik Zimmer (2019, p. 3), the intended aim of GAAR is, inter alia, to ensure equal treatment of taxpayers.

Revisiting the thoughts of Saint Thomas Aquinas and Aristotle, Amatucci argues

The fairness of the tax is thus largely based upon the principle of the equality of the proportion of the tax to the ability to pay. The formal cause contains an objective element (the common good) and a subjective one (ability to pay). Distributive justice requires that the tax be imposed on each taxpayer according to his ability to pay [...] The concept is astonishingly up to date. (Amatucci, 2016, ch. 1.2.2.)

The ability to pay is also recognized in Estonian law (Lehis, 2012, p. 63).

In case of receiving shares in the company in consideration for making a non-monetary payment to the equity and assuming it meets the first criteria of the income increase in the balance of assets, it should be treated as nonrealized income. Such income is outside of the scope of taxable income of a natural person shareholder. 


\subsection{Conclusions on the ATAD GAAR}

The author concludes, based on the above, that the Estonian general domestic anti-avoidance rule does not override the concept of income and taxable objects and it follows the principles of objective taxation and the economic content of a transaction. Even if the consideration of benefitting from the deferred tax treatment may be one of the driving motives for the taxpayer, and the commercial reasons are not fully present in the economic reality, the law does not require introducing new taxable objects which would deviate from objective taxation. Estonian domestic approach to antiabuse rule follows the objective concept of "wholly artificial arrangements" as stated in the Cadbury Schweppes [2006] case.

So what can we deduce from the Estonian approach to the GAAR in ATAD, provided we can interpret ATAD GAAR in the same manner and with the same functionality as Estonian general domestic anti-avoidance rule in Section 84 of the TA? The sovereignty of Member States to decide what to tax can be achieved by interpreting Article 6(2) of the ATAD so that the genuineness of an arrangement is treated as an objective category and it eliminates arrangements only if they are not objectively real. It would require deviating from the wording of commercial reasons which can be seen as a subjective category when being interpreted in a literal sense. A similar approach is described by Zimmer, who summarized the function of antiavoidance rules as follows: "However, in most cases it is rather clear that the immediate effect of applying the GAAR is to remove the tax benefit, which normally means basing the tax assessment on recharacterized facts derived from the economic reality of the arrangement" (Zimmer, 2019, p. 11).

\section{Conclusion}

The author was driven to write this article due to some level of illogicality one can find in ATAD-its grammatical interpretation requires elimination of certain arrangements from taxation, but this may lead to overall nontaxation if there is no alternative tax base in domestic laws. This is caused by involving a subjective element in the elimination test. Inspired by this, the purpose of this article was to analyse whether Article 6 of the ATAD requires the EU Member States to impose new taxable objects regardless of the literal interpretation of Article 6(3), which recognizes the full sovereignty of Member States to decide what to tax. The author argues that the answer 
to the research question is "no", which means that the Member States are not required to impose new taxable objects.

The contextual interpretation placing the requalification rule of Article 6(3) in the context of the primary EU law (specifically, Arts. 113 and 115 of the TFEU) demonstrates that the purpose of the ATAD is not to harmonize taxable objects but to provide an additional tool for the national legislature to fight abuse of existing tax law. Taking the opposite position would be highly questionable in the context of the principle of subsidiarity, which was a general concern of the Swedish and Maltese parliaments when the ATAD was introduced.

As for travaux préparatoires, removing the requirement to tax based on the economic substance best demonstrates how much freedom the EU legislature intends to leave to the Member States to decide what to tax and what not to tax. The purpose of the ATAD is to protect national tax sovereignty and not to limit it by introducing the concept of subjective taxation.

Both the effet utile test and the comparative analysis of the Estonian domestic GAAR's approach to the Scheme demonstrate that the conflict between the elimination stage and requalification stage of the ATAD can be overcome if the concept of the genuineness of an arrangement is seen as an objective category and the anti-abuse rule is interpreted coherently in the existing EU case-law on such measure. The path for such interpretation is opened by the CJEU in its recent judgment in joined cases of $N$ Luxembourg 1 and Others $v$. Skatteministeriet [2019]. Hopefully, the future case-law of the CJEU confirms that such an approach could also be adopted in the context of the ATAD GAAR.

Kaido Künnapas, PhD, is a senior lecturer at the TalTech Law School of Tallinn University of Technology and a senior associate at the tax practice group of Sorainen Law Firm. Künnapas obtained his PhD from the Faculty of Law of the University of Tartu and is a member of the Estonian Bar Association. His research interests include taxation law, international taxation law, civil procedure law, administrative court procedure law and legal environment of business. 


\section{References}

Amatucci, A. (2016), 'Foundation of the contemporary ability-to-pay principle in taxation in the thought of Saint Thomas Aquinas,' in H. Jochum et al. (eds.) Practical Problems in European and International Tax Law: Essays in Honour of Manfred Mössner, Amsterdam: IBFD, ch. 1.

Cadbury Schweppes plc and Cadbury Schweppes Overseas v. Commissioners of Inland Revenue [2006], CJEU C-196/04, ECLI:EU:C:2006:544.

Cédelle, A. (2016), The EU Anti-Tax Avoidance Directive: A UK Perspective, Oxford University Center for Business Taxation Working Paper Series, WP 16/14.

Collier, R.; Kari, S.; Ropponen, O.; Simmler, M. \& Todtenhaupt, M. (2018), Dissenting the EU's Recent Anti-Tax Avoidance Measures: Merits and Problem, EconPol Policy Report, no. 08, vol. 2.

Commission Proposal for a Council Directive laying down rules against tax avoidance practices that directly affect the functioning of the internal market, COM(2016) 26 final, 2016/0011 (CNS), 28.1.2016.

Communication from the Commission to the European Parliament and Council for an Action plan to strengthen the fight against tax fraud and tax evasion, COM (2012) 8806 final, 6.12.2012.

Consolidated version of the Treaty on the Functioning of the European Union, OJ C 326, 26.10.2012, pp. 47-200.

Council Directive 2003/49/EC of 3 June 2003 on a common system of taxation applicable to interest and royalty payments made between associated companies of different Member States, OJ L 157, 26.6.2003, pp. 49-54. Council Directive (EU) 2011/96/EU of 30 November 2011 on the common system of taxation applicable in the case of parent companies and subsidiaries of different Member States (recast), OJ L 345, 29.12.2011, p. 8.

Council Directive (EU) 2016/1164 of 12 July 2016 on laying down rules against tax avoidance practices that directly affect the functioning of the internal market, OJ L 193, 19.7.2016, pp. 1-14.

de Wilde, M. F. (2018), 'Is the ATAD's GAAR a Pandora's box?' in P. Pistone \& D. Weber (eds.) The Implementation of Anti-BEPS Rules in the EU: A Comprehensive Study, Amsterdam: IBFD, pp. 301-328. https://doi.org/10.2139/ssrn.3040709

Estonian Commercial Code, RT I 1995, 26, 355; RT I, 28.02.2019, 1. Estonian Income Tax Act, RT I 1999, 101, 903; RT I, 19.03.2019, 13. Estonian Law of Obligations Act, RT I 2001, 81, 487; RT I, 20.02.2019, 2. 
Estonian Taxation Act, RT I 2002, 26, 150; RT I, 06.11.2019, 1.

Explanatory memorandum to the bill of law no. 705 SE on amendments to the Income Tax Act, Estonian Parliament, 12.12.2018. Retrieved from https://www.riigikogu.ee/tegevus/eelnoud/eelnou/97180f59-7b6f4797-aa2d-d6604039633b [accessed 1 Jan 2020]

Gutmann, D. et al. (2017), 'The impact of the ATAD on domestic systems: a comparative survey,' European Taxation, vol. 57, no. 1, pp. 2-20.

Her Majesty's Commissioners of Revenue and Customs v. Newey [2013], CJEU C-653/11, ECLI:EU:C:2013:409.

Kallas v. Estonia [2017], Criminal Chamber of the Estonian Supreme Court, no. 1-15-9051, 6.10.2017.

Kõrgesaar v. Tax Board [2001], Administrative Chamber of the Supreme Court, no. 3-3-1-57-00, 15.1.2001.

Lazarov, I. \& Govind, S. (2019), 'Carpet-bombing tax avoidance in Europe: examining the validity of the ATAD under EU law,' Intertax, vol. 47, no. 10, pp. 852-868.

Lehis, L. (2012), Maksuõigus [Tax law], 3rd ed., Tallinn: Juura.

Lenaerts, K. \& Gutiérrez-Fons, J. A. (2013), To Say What the Law of the EU Is: Methods of Interpretation and the European Court of Justice, Distinguished Lecture delivered on the occasion of the XXIV Law of the European Union course of the Academy of European Law, on 6 July 2013, EUI Working Papers, AEL 2013/9.

Lind, K. (2003), 'Tulu mõiste' [The definition of income], Juridica, no. 5, pp. 338-348.

Maisuradze, L. (2017), The Anti-Avoidance Directive and its Compatibility with Primary EU Law, MA thesis defended at the Faculty of Law of the University of Lund.

Maret Lilleorg v. Tax Board [2012], Administrative Chamber of the Estonian Supreme Court, no. 3-3-1-79-11, 13.2.2012.

Marge Sirge v. Tax Board [2011], Administrative Chamber of Estonian Supreme Court, no. 3-3-1-15-11, 25.4.2011.

N Luxembourg 1 and Others v. Skatteministeriet [2019], CJEU Joined Cases C-115/16, C-118/16, C-119/16 and C-299/16, ECLI:EU:C:2019:134.

O. and B. v. Minister voor Immigratie, Integratie en Asiel [2014], CJEU C-456/12, ECLI:EU:C:2014:135.

Opinion of the Advocate General Mr Leger in the case of C-196/04 Cadbury Schweppes plc and Cadbury Schweppes Overseas v. Commissioners of Inland Revenue, 2006 I-07995, 2.5.2006, ECLI:EU:C:2006:278.

OÜ AH Seenior v. Tax Board [2017], Administrative Chamber of the Estonian Supreme Court, no. 3-3-1-78-16, 9.6.2017. 
Philip Morris Brands SARL and Others v. Secretary of State for Health [2016], CJEU C-547/14, ECLI:EU:C:2016:325.

Piantavigna, P. (2018), 'The role of the subjective element in tax abuse and aggressive tax planning,' World Tax Journal, vol. 10, no. 2.

Pistone, P. et al., eds. (2019), Fundamentals of Taxation: An Introduction to Tax Policy, Tax Law and Tax Administration, Amsterdam: IBFD.

Polbud - Wykonawstwo [2017], CJEU C-106/16, ECLI:EU:C:2017:804.

Rigaut, A. (2016), 'European Union - anti-tax avoidance Directive (2016/1164): new EU policy horizons,' European Taxation, vol. 56, no. 11, pp. 504-505.

Saare, K.; Volens, U.; Vutt, A. \& Vutt, M. (2015), Ühinguõigus I [Company law], Tallinn: Juura.

Schønberg, S. \& Frick, K. (2003), 'Finishing, refining, polishing: on the use of travaux preparatoires as an aid to the interpretation of community legislation,' European Law Review, vol. 28, no. 2, pp. 149-171.

Statement by the Committee on Taxation 2015/16:SkU28, Subsidiarity check of proposal for a Council Directive laying down rules against tax avoidance practices that directly affect the functioning of the internal market (COM(2016) 26). Reasoned opinion from the Swedish Parliament. Retrieved from https://secure.ipex.eu/IPEXL-WEB/scrutiny/ CNS20160011/serik.do [accessed 1 Jan 2020]

Zimmer, F. (2019), 'OECD/European Union/International - In Defence of General Anti-Avoidance Rules,' Bulletin for International Taxation, vol. 73, no. 4. 